\title{
The Effect of Network Practices on the Identification Processes among Young People in the Circumstances of Sociocultural Risks
}

\author{
Asiet Yusufovna Shadje \\ Elena Sergeevna Kukva
}

Federal State Budget Institution of Higher Professional Education «Adyghe State University» (ASU)

385000, Maikop, street Pervomayskaya, 208, Russian Federation; Email: nisadgu@yandex.ru

\section{Doi:10.5901/mjss.2015.v6n5s2p46}

\begin{abstract}
The article analyzes the role and place of network practices in the identification of young people in the circumstances of sociocultural risks. The insight into the information and communication environment in the context of modern science is provided; the positive and negative aspects of its controversial influence on young people are revealed. The transformation of the axiological space of the Russian language as one of the unifying phenomena typical of the current stage of the development of our society is analyzed. The attention is paid to the peculiarities of the processes of identification of young people in the North Caucasus. The effectiveness of detection and use of the heuristic capabilities of network practices in the complex nonlinear identification processes is substantiated. The research is of interdisciplinary nature: the principle of consistency, the synergistic and sociocultural approaches, and the comparative method were used. The authors conclude the following: The information network is a) non-linear, b) open c) uncertain. And the youth are to be taught how to work in the network space. It aims at identifying and using the heuristic capabilities of network practices in the identification processes, at a) understanding the complex unity in diversity, b) realizing that the national, regional, and ethnic identities in modern Russia are based on new value-related and ideological references, which are formed on the basis of the civil culture preserving the sociocultural diversity; c) the need for a network approach as a resource to strengthen Russia's national identity.
\end{abstract}

Keywords: youth; identification; complex non-linear system; network practices

\section{Introduction}

The changes occurring in the modern world and in Russia of the post-Soviet period are actively reflected on the formation of active civic engagement of young people. For Russia, the problem now is of particular importance. It is no secret that the Russian system reforms of the late twentieth century were accompanied by the refusal of the state from the youth policy of the mobilization type. For 20 years of reforms in our country, a new generation has grown up who have an ambivalent attitude to the past. For this period, we have lost many values. The processes of disintegration of the youth have intensified, as well as the growth of consumer attitudes, the manifestation of social passivity of its one part, and the rise of aggression of the other.

While in the Soviet period, the satisfaction of interests was determined by the dominant ideology, the modern Russian situation has changed so much that all backbone grounds of the sociocultural space have transformed. This is a fairly complex and ambivalent process, which is related not only to the socioeconomic crisis, but also to the crisis of value references of youth's socialization, as well as identification of the highest form of socialization.

As is known, the recognized institutional sociocultural factors that shape the axiological worldview of young people are the policy, mass media, and education, which are implemented by means of purposeful actions in relation to the youth as a structural unit of the society. However, as our research shows, the regional, ethnic, and globalization factors, being the cultural factors, are implemented through shared ideas and values. The optimal combination of these factors is rather difficult, but necessary.

The purpose of this article is by considering the new forming type of identity (the "network type") in the circumstances of sociocultural risks to actualize the need for using the constructive potential of network practices in the interaction of the mechanisms of self-organization and management of processes in the youth environment. 


\section{Materials and Methods}

The research is of interdisciplinary nature: the principle of consistency, the synergistic and sociocultural approaches, and the comparative method were used.

\section{Results and Discussion}

In modern conditions, as is known, the information communication factor has been activated, which has remarkably changed the sociocultural space of the society. The complex changes taking place in it threaten the modern human with new sociocultural risks. Specialists consider the following as sociocultural risks (Astafieva, 2004):

- "delay" in cultural development, which leads to inequality of information and communication;

- excess of the scope and role of information flows;

- loss of the basic characteristics by ethnic cultures, which results in the transformation of the ethno-cultural identity;

- " "hollowing out" of the core of the ethnic language as a result of the expansion of the linguistic information borrowings needed for communication in the global information space;

- negative self-organization, and lost opportunities due to lack of innovation strategy and cultural policy.

These provisions outline the scope of our further reflections - consideration of the influence of network practices on the multilevel identity — national, regional, and ethno-cultural, focusing on a number of key identification markers.

\subsection{Transformation of the axiological space of the Russian language}

In this regard, we would like particularly to mention how the situation with the Russian language - the common component of the Russian identity in the identification space of the country - is changing.

In today's global information space, the "hollowing out" of the core of the Russian language takes place, resulting in the worsening spiritual/cultural crisis in our country. We lose our cultural value, on which the national unity of the country is based. After all, the Russian language is not only the language of the ethnic Russians, not only the means of communication with representatives of different ethnic groups. It is a force that unites us in culture, economics, politics, etc., a means of preserving and strengthening our friendship. The Russian language is the foundation of our peace and our mutual understanding. Therefore, all of us must be bound with the same desire and goal — to preserve the cementing force, to strengthen our cooperation and unity of our country. The Russian language in the first place exists for us, the Russian citizens, and it must receive its existence from us.

Serious problems with the Russian language exist not only in the world, but also in our country and its regions. The quality indicators of the proficiency in the Russian language are not very promising (as evidenced by the results of the unified state exam and the entrance exams in the Russian language in higher education institutions, as well as the results of the initiative action "Total dictation," which was written with an "excellent" mark only by $2 \%$ of participants). There is a whole battery of reasons for this. One of the key reasons is the spiritual, cultural, educational, economic, and political crisis in our country, which has resulted in a decline in the interest in reading and the attraction to television viewing and the Internet consumption. We believe that television and the Internet are the greatest achievements of humanity, allowing us to engage in the global sociocultural process. Today, the most important task is the search for harmony of different kinds of culture: reading, television viewing, and networking. The Russian language plays a crucial role in these processes.

Thus, the Russian language is not only the language of the ethnic Russians, not only a means of communication with representatives of different ethnic groups. The Russian language is a general cultural value, on which the unity of our country is based. It is a force that unites us in culture, economics, politics, etc. The Russian language is a means of preserving and strengthening our friendship. It is the foundation of our peace and our mutual understanding. Therefore, all of us are bound with the same desire and goal — to preserve the cementing force, to strengthen our cooperation and unity of our country. The Russian language in the first place exists for us, the Russian citizens, and it receives its existence from us.

It is important to unite the efforts of the state, educational, scientific and cultural institutions, public organizations, of all people, aimed at the implementation of new opportunities for the preservation, development, and dissemination of the Russian language. This does not negate the need for maintaining a large number of ethnic languages in our country. But today, it is necessary to understand the value of the Russian language, which is the unifying factor of the Russian ethnic 
groups, of the Russian nation. The Russian language should help us realize our commonality and that we (regardless of ethnicity and religion) are the citizens of great Russia.

Therefore, it is important to understand and take practical measures to preserve the national language, which is the tie of the Russian civil identity and forms the basis of the identification space.

\subsection{Self-identification of the youth in the information communication space}

The identification medium is a nonlinear medium (system), in which the cultural traditions and values, the regional and national forms of identity coexist. Meanwhile, the virtualization of the society leads to changes in the hierarchical relationship between tradition and innovation, the local and the global, the whole and the part. The virtual reality creates a new reality, which forms in the minds of the youth a new axiological attitude. Thus, the information communication space of the Internet "absorbs" the man and begins to dictate its own rules. This active force and forceful intervention in the natural environment identity - a complex system — destroys it and opposes the artificial world to the real. According to Delokarov, the personality in such a system is formed from the outside, and is not "self-determined" (Delokarov, 2001)

Replacing the natural identification environment, in our case, of the multiethnic society, with an artificial simulacrum - the network practices - entails the creation of a "special semiotic space (Lotman), which forms specific, fragmentary consciousness. This consciousness and "burdened" natural languages are not conducive to understanding the life, the bypassing events. A young person in such a situation would choose the easy way of "comprehension" of the life, i.e. he starts minutely to "catch" and record information. The destroying system is the natural sociocultural space, in which the identification takes place and promotes the formation of not a thinking person, but an observing one.

Thus, identification space of the youth becomes the space, in which identification takes place spontaneously, i.e. the identification markers are what brings virtuality in the sociocultural space of children, adolescents, and youth. The fact should also be noted that the identity chain - family - kindergarten - school - university - social institutions - is torn in the virtual space. This occurs due to the weakening of functions of social institutions.

To paraphrase the succinct and appropriate modern term of Fukuyama "spontaneous socialization" (Fukuyama, 2008), we can say that there is a period of "spontaneous identification" under the influence of network practices. In the consciousness of the young people, contradictory processes emerge that are associated with mutual influence of different cultures, values, which are the identification markers added to the virtual world of the young people. The cultural values that have historically formed in the family and in a certain cultural space, by which values a person identifies himself and his place in the society, are being erased, or come to a standstill with the new ones. The identification crisis is observed not only at the level of individual consciousness, but also at the community level.

An important aspect of this process is the problem of filling the identification space with aggression, cruelty, and violence, which are actively broadcast by mass media and are cultivated in the minds of the young people. This sociocultural atmosphere certainly has a negative impact on the formation of patriotism, a sense of belonging to one's own country and civic awareness among young people. Contradictions of the social development of young people, in particular the identity changes and contradictions in our country were determined by Chuprov: "The reproduction of civic consciousness retains the overall thrust of the formation of identity in the modern society, but it has slowed down the pace. Many contemporary trends, such as the individualization of consciousness, formation of the enterprise proceed in an exaggerated way, almost on the brink of deviations. The contradictions arising in this regard are also due to the state of the value-related regulatory uncertainty in the country, have sociocultural roots, and manifest themselves in the negative nature of the change in the traditional and modern civil identifications; in the negative change dynamics of the traditional identifications with one's own country" (Chuprov, 2012).

The identification situation in the North Caucasian multiethnic society under the influence of the contemporary social practices becomes even more complicated and uncertain. This is due to the peculiarities of the sociocultural space and the specifics of the regional culture. Despite the modernization of the North Caucasus, the ethnic factor remains the main parameter of the order, determining the functioning of the complex multiethnic and multiconfessional system (Shadzhe and Kukva, 2012; Kukva, 2012; Shadzhe and Hatsats, 2012). The process of identification of the young people in the region becomes more complicated. Within the process, the young people try to show at all costs their ethnic/Caucasian origin in the society, seeking to stand out. As a result, the youth finds themselves in an identification dead-end. This requires the formation of understanding of the relationship "I" and "we," understanding of the relationship of the ethnocultural, regional, and Russian identities.

In the information communication space, the demarcation between people on the one hand, and between the real world and the artificial one offered by network practices, on the other hand, takes place. The natural processes of selfidentification are replaced by new, artificial processes. All of this is the cause of exacerbation of the sociocultural identity 
of the young people, as well as the formation of a new, "network" type of identity. In search of new identities, "also artificial structures, such as Aum Shinrikyo and other sects, can be created where the lack of historical types of identity is replaced by bizarre, strange, and dangerous conglomerates of consciousness" (Petrova, 2010). From this perspective, the network practices cannot be seen as a progressive element of the modernization project only.

Of course, living in the global world, we have to fit into the existing order of things, for which we need to expand the ideological framework, and to learn to live and work in a "new media phenomena" (Castells, 1990).

This fact allows us to address the new network structures in the new paradigm, which have justified their activities in Russia and abroad, as well as the network approach. In modern conditions, all aspects of our being are affected by the network paradigm. The concept of "network" began to be used actively and extensively, in various contexts: social, political, economic, physical, chemical, etc. We share the view of Moskalev, according to which a network is understood as a non-linear heterogeneous structure of interacting objects that maintain their unity in communication (Moskalev, 2007).

According to Castells, networks "do not just provide the organization of activities and sharing of information. They practically act as the creators and distributors of cultural codes, not only within a single network, but also in a variety of forms of interchanges and interactions... Their most successful campaigns, most striking initiatives are often the result of "turbulences" that occur in the interactive network of multi-level communication" (Castells, 1990).

Recently, a set of virtual corporations, educational systems, universities, whose activity is interdisciplinary, have emerged. Let us refer to the virtual research group of identity. The recent emergence of the need for systematization of knowledge on the issues related to the study of identity and, in the long term, to the development of a common research strategy dictated the need for consolidated efforts of the Russian scientific community, which is engaged in this subject in a variety of scientific disciplines. The website of the "Expert Network for Identity Research" (Identity World) was established to:

- create a database of researchers and centers emgaged in this subject;

- form an electronic library of available publications of Russian researchers (including publications and theses);

- coordinate the research strategies within the framework of development and discussion of the key areas of research;

- in the long term - to carry out scientific events (round tables, seminars, conferences) and prepare joint publications, including subject-related issues of scientific journals and collections of articles.

Of course, the expert network on the study of identity, on the one hand, has the cognitive and communication functions, and on the other hand, allows "improving the efficiency of the transfer of knowledge and technology" in the field of identification processes.

Let us consider another example. In order to strengthen civic identity among Russians in 2009-2011, various projects were implemented in our country. The creation of a specialized Internet portal (One country) was aimed at knowing the peoples of Russia, cultural experience, and interaction in the same multiethnic house.

Finally, to sum up our considerations, we would like to identify a number of provisions that could have a positive impact of the network practices on the strengthening of the Russian identity at the regional level:

- We must use the heuristic capacity of the network practices, i.e. their focus on the proper ideology - the Russian national idea, aimed at identifying the unifying ties of the cultural diversity and strengthening the unity of the multiethnic people of Russia.

- With account of the high level of influence of mass media on parenting tolerant and dialogical relations in the society, the information and broadcasting programs should include articles and programs dedicated to the formation and strengthening of the Russian identity, inter-ethnic tolerance, and uniting the Russian nation.

- We must encourage the network practices aimed at understanding by the young people that the national, regional, and ethnic identity in modern Russia are based on new value-related and ideological references, which are formed on the basis of civic culture with the preservation of the sociocultural diversity. In this regard, the formation of ideas about the constructive role of the relationship of identities, which is seen as a mechanism to overcome the tensions in the multiethnic and multiconfessional region, seems relevant and needed.

- It appears that such work can and should be done by the elite of the region provided the science and politics join their efforts, using heuristic ideas of a civic nation in solving this problem, and activating the work on approval of the concepts "Russian nation" and "Russian identity," showing the integrating meaning of these phenomena.

- We should actively use the regional potential for the formation of an integrating image "we -the Russians" and its perception in the public mind. This requires specification in the orientation of the youth policy of the 
main provision relating to the fact that the Russian identity and Russian nation do not entail unification, i.e. disappearance of ethnic groups and ethnic identities. On the contrary, the Russian, regional, and ethnic identities can coexist and complement each other.

\section{Summary}

The emergence of network projects aimed at increasing the level of tolerance, eradication of ethnophobia and extremism today has become a necessity of time. Self-identification of young people in the virtual world gives grounds to think that it is often difficult to determine what kind of network practices is a greater danger. One thing is for sure - it is a complex irreversible process contributing to the emergence of specific cultural models and patterns, increase in the tensions in the interaction of the tradition and innovation in cultures.

The effect of network practices on the identification processes among young people in the circumstances of sociocultural risks cannot be assessed unambiguously. Therefore, on the one hand, experts in the ethnosphere field can and should guide the mechanism for strengthening civil solidarity. It is difficult because the information network is a) nonlinear, b) open c) uncertain. And the youth are to be taught how to work in the network space. On the other hand, these qualities make the information network and network practices accessible and attractive. It aims at identifying and using the heuristic capabilities of network practices in the identification processes, at a) understanding the complex unity in diversity, b) realizing that the national, regional, and ethnic identities in modern Russia are based on new value-related and ideological references, which are formed on the basis of the civil culture preserving the sociocultural diversity; $c$ ) the need for a network approach as a resource to strengthen Russia's national identity.

\section{Acknowledgements}

This research project was supported by the Ministry of Education and Science of the Russian Federation, Project No. 1152.

\section{References}

Astafieva, O.N. (2004). Modeli etnokul'turnoi identichnosti v sovremennom informatsionno-kommunikativnom prostranstve [Models of ethnocultural identity in modern information communication space]. Vestnik bibliotechnoi assamblei Evrazii -Bulletin of Library Assembly of Eurasia, 3,4 [in Russian].

Castells, M. (1990). Mogushchestvo samobytnosti. Novaia postindustrial'naia volna na Zapade. Antologiia [Power of originality. The new wave of post-industrial West. Anthology], Inozemtsev, V.L. (Ed.). Moscow: A [in Russian].

Chuprov, V.I. (2012). Metodologiia, teoriia i istoriia sotsiologii: sbornik nauchnykh statei [Methodology, theory and history of sociology: a collection of scientific articles]. Metodologiia, teoriia $i$ istoriia sotsiologii -Methodology, Theory and History of Sociology: Proceedings of the Scientific Conference (Rostov-on-Don, 11-12 November 2011). Filonenko, V.I. (Ed.). Rostov-na-Donu: Izd SKNTS VSH [in Russian].

Delokarov, K.Kh. (2001). Globalizatsiia i problemy ustoichivosti sovremennogo mira. Globalizatsiia i filosofiia [Globalization and stability problems of the modern world]. Globalization and Philosophy]. Moscow [in Russian].

Fukuyama, F. (2008). Doverie: sotsial'nye dobrodeteli i put' k protsvetaniiu [Trust: The Social Virtues and the Creation of Prosperity]. Moscow: AST [in Russian].

Identity World, Website. Retrieved from identityworld.ru [in Russian].

Kukva, E.S. (2012). Identichnost' na Severnom Kavkaze: resurs sinergetiki [The identity of the North Caucasus: the resource synergy]. Sotsial'no-gumanitarnye znaniia -Socially-Humanitarian Knowledge, 5. [in Russian].

Moskalev, I.E. (2007). Samoorganizatsiia setevykh struktur nauchnykh kommunikatsii. Sinergeticheskaia paradigma. Sinergetika obrazovaniia [Self-organizing networks of scientific communications. Synergetic paradigm. Synergetics education]. Moscow: Progress-Traditsiia [in Russian].

One country, Website. Retrieved from www.stranaodna.ru [in Russian].

Petrova, E.V. (2010). Problema sokhraneniia kul'turnogo mnogoobraziia v global'nom informatsionnom obshchestve [The problem of preserving the cultural diversity in the global information society]. Globalizatsiia i problema sokhraneniia kul'turnogo mnogoobraziia -Globalization and the problem of preservation of cultural diversity. Institute of Philosophy of RAS, Khen, Iu.V. (Ed.). Moscow: IF RAN [in Russian].

Shadzhe, A.lu., \& Hatsats, A.A. (2012). Mezhetnicheskoe soglasie i ukreplenie rossiiskoi identichnosti na Severnom Kavkaze [Interethnic harmony and strengthening of the Russian identity in the Northern Caucasus]. Sotsial'no-gumanitarnye znaniia -SociallyHumanitarian Knowledge, 5. [in Russian].

Shadzhe, A.lu., \& Kukva, E.S. (2012). Moderniziruiushchiisia Severnyi Kavkaz: parametry identichnosti [The modernizing North Caucasus: the parameters of identity]. Vestnik MGOU. Seriia "Filosofskie nauki» -Herald MGOU. A series of "Philosophical sciences", 2 [in Russian]. 